\title{
Unlocking Technology Adoption for a Robust Food Supply Chain: Evidence from Indian Food Processing Sector
}

\author{
Vranda Jain $^{1}$, Tavishi Tewary ${ }^{2}$, Badri Narayanan Gopalakrishnan ${ }^{3}$ \\ ${ }^{1}$ Jaipuria Institute of Management, \\ A 32 A Sector 62 Noida - 201309 (U.P.), India. \\ E-mail: vrandajain@gmail.com \\ 2 Jaipuria Institute of Management, \\ A 32 A Sector 62 Noida - 201309 (U.P.), India. \\ E-mail: tavu.tavishi@gmail.com \\ ${ }^{3}$ University of Washington, \\ Washington, Seattle, WA, USA \\ E-mail: vranda.jain@jaipuria.ac.in
}

This paper pioneers the identification of artificial intelligence (AI) enablers like technology feasibility, sophistication, data integrity, interoperability and perceived benefits that can boost operational efficiency of firms in Indian food processing industry. With the food processing industry contributing significantly to domestic gross value added and generating an export earning of close to USD 40 billion from agricultural and processed food exports, the study examines the role of $\mathrm{AI}$ in overcoming the existing inefficiencies of firms, particularly the small and medium enterprises (SMEs) involved in food processing. For this, questionnaire was circulated to 500 respondents comprising of IT and supply chain professionals, managers of food processing companies and academicians working in this domain, of which 341 complete responses were received. These responses were then analysed using PLS-SEM modeling, through which the relationship between AI adoption and operational efficiency of firm was established. The study found a significant relationship between AI adoption and operational efficiency. The R square and $Q$ square values substantiate the predictive power of the model used in the study. The research has significant implications for supply chain professionals as technology adoption would boost resilience, integration and transparency of these firms. The study is also relevant for addressing issues pertaining to food security,

Vranda Jain - Assistant Professor.

Tavishi Tewary - Assistant Professor.

Badri Narayanan Gopalakrishnan - Professor, University of Washington, Seattle.

The article was received: 03.01.2021/The article is accepted for publication: 10.02.2021. 
employment generation, enhancing industrial output and export growth. Policymakers can also get perspectives on harnessing the benefits of AI technology while creating an enabling environment for different supply chain partners.

Key words: Supply Chain Management; SMEs; Disruptive Technology; Food Processing Industry; PLS-SEM; India.

JEL Classification: 033, C38, Q16.

DOI: $10.17323 / 1813-8691-2021-25-1-147-164$

For citation: Jain V., Tewary T., Gopalakrishnan B.N. Unlocking Technology Adoption for a Robust Food Supply Chain: Evidence from Indian Food Processing Sector. HSE Economic Journal. 2021; 25(1): 147-164.

\section{Introduction}

A well-managed supply chain improves communication [Huo et al., 2016], imparts flexibility [Rajesh, 2017], reduces risks [Nooraie et al., 2020], promotes supervision over strategies [Bechtsis et al., 2017], enhances productivity [Sharma et al., 2020], and decision making [Tiwari et al., 2018]. Extant literature has highlighted the link between improvement in supply chain management systems and business performance. Achieving an effective supply chain, however, is challenging owing to varied uncertainties and improper coordination between partners and activities [Li et al., 2015]. Due to the higher level of uncertainty and risks involved in food supply chains (FSCs), establishing a robust, resilient, and sustainable supply chain in the food processing industry (FPI) is even more complex and affects the information quality and efficiency [Hsiao et al., 2010; Haleem et al., 2019]. On the other hand, there are increasing instances of the need on part of exchange partners to infuse transparency, widen information exchange and improve traceability in FPIs. By integrating disruptive technology like artificial intelligence (AI) in their operations, overcoming such challenges and controlling external factors like market behavior and policies, visualizing future trends, and boosting revenues of stakeholders involved in food processing can be more effective [Baryannis et al., 2019]. Thus it is imperative to move from the traditional ways of doing business and implementing innovative technologies.

The processed food market in India is expected to grow at a CAGR of 14.6 per cent to reach USD 543 billion by 2020 . With close to 40,000 registered units, the industry employs 1.93 million people and is the fifth-largest contributor to India's GDP [MOFPI, 2019]. Over the years the sector has witnessed a changing trend from being sustenance oriented to market-driven. Apart from meeting domestic demand, the 127 agro-climate zones comprising of dairy, poultry and meat processing, fruits and vegetables, fisheries, etc. cater to global consumers [FAO, 2019] and generate foreign exchange. The forward and backward linkages with agricultural production, packaging, logistics, research bodies, etc. impart complexity and prominence to this industry. Being one of the largest agro-food producers [WTO, 2018] with ample growth potential, the sector has been recognized as a sunshine sector and has grabbed attention in terms of launch and implementation of various schemes by the Ministry of FPI. Despite such support received by small and medium enterprises (SMEs), whose dominance in the industry is visible [Grand 
Thornton - Assocham, 2017], the processing of agricultural produce is only about 20 per cent. Further, a recent McKinsey report (2018) estimates industry wastage to be around USD 8.5 billion. Extant literature has reviewed this situation and identified probable causes of inefficiency in SMEs operations. Few such barriers to SME growth are credit constraints, high collaterals and guarantees against loans, discriminatory regulations, inadequate infrastructure, information and market linkages, and restricted production capability [Kumar \& Rao, 2016]. Several studies have suggested solutions to overcome these barriers [Augustin et al., 2016; Balaji, Arshinder, 2016]. However, there is a dearth of theoretical and empirical studies on the role of technology in overcoming these challenges and deriving favorable outcomes by improving supply chain management in this sector.

FSC consist of 5 stages- inputs, pre-harvest, post-harvest, warehouse- cum- storage, and distribution including retail. A digitalized FSC can make the real-time monitoring of material flows possible which would contribute to increasing flexibility and speed and imparting visibility to potential risks and can therefore help in scenario planning accordingly. Past studies have shown that AI can contribute in sensing, designing, monitoring, organizing, managing, predicting decision making, adaptive learning, and other basic functions in FSCs [Köhler, Pizzol, 2020]. Researchers have also focused on higher transparency and facilitating effective recall in form of greater trust in FSCs [Francisco, Swanson, 2018] as a benefit of AI adoption. In a nutshell, extended visibility and traceability [Behnke, Janssen, 2020], better governance [Saberi et al., 2019], centralized architectures [Mezquita et al., 2019], reduction in food wastage [Ali et al., 2019], automating data collection [Kittipanya-Ngam, Tan, 2020], reducing errors in orders [Tijan et al., 2019], better management of conditions like moisture and improved supply chain processes are few benefits derived from using modern-day technologies in FSCs. The present study reviews the benefits of AI implementation in the processing phase of FSCs. This is carried out through techniques like heating, cooling and drying so as to process the raw materials into useful products with some shelf life [Augustin et al., 2016]. Although recent studies have shown AI's beneficial effects in this processing phase in reducing food wastage [Song et al., 2018] and optimizing CO2 reduction during processing of grains [Chandrasekaran, Ranganathan, 2017], there is a need to further explore the benefits of AI adoption in the processing stage of FSC.

This study contributes to the existing literature on operational efficiency by reviewing the facilitators of AI adoption. The study determines significant factors like technology feasibility, sophistication, data integrity, interoperability, and perceived benefits that can contribute to technology implementation in the Indian food processing industry, particularly by the SMEs. Further, the study examines the impact of AI technology on operational efficiency of these firms, via three pillars of resilience, transparency, and integration. Being the world's second-largest agricultural producer [FAO, 2019], Indian agricultural and processed food exports amounted to USD 38.49 billion [CII, 2019]. Domestically, FPI contributes 8.8 and 8.39 percent of GVA in manufacturing and agriculture respectively [MOFPI, 2019]. The current study recognizes the dynamic integration and prominence of Indian FPI in ensuring food security for the growing population, absorbing more labor, generating higher contribution in economic growth and exports by enhancing industrial output and a better realization of advantageous factors like rich and diverse resource endowment. Since the traditional Indian food SCM has fragmented, inconsistent and discrepant data and suffers from poor interoperability and information traceability [Gunarathne et al., 2018], adoption of disruptive technologies can provide a panacea to overcome these problems. The changing trends in consumer demand in terms of sharing product information and 
labeling (like quality, authenticity, safety, etc.) and effective traceability in the wake of recent global FSC scandals (for example, the Chinese melamine scandal) has necessitated technological usage. The novelty of this research lies in identifying the facilitators influencing AI adoption and assessing the impact of technology usage in overcoming inefficiencies of SMEs associated with FPI in Indian context.

The rest of the paper is organized as follows. Section 2 discusses the relevant literature on operational efficiency, supply chain resilience, transparency and integration, enablers of technology adoption. Sections 3 discusses the methodology. Section 4 discusses the results and implications of our study. Conclusions of the study are highlighted in Section 5.

\section{Literature review}

The multidimensionality of supply chains has been discussed extensively in supply chain literature [Bevilacqua et al., 2020; Ahi et al., 2016; Halley, Beaulieu, 2010]. In recent years, a critical development- digitalization of supply chains has led to the replacement of conventional supply chain structures. Apart from bringing out a paradigm shift in the conduct of transactions [Tapscott, Tapscott, 2017], it has contributed to enhancing the efficiency, responsiveness, and performance of businesses [Craighead et al., 2017]. This study postulates that the implementation of these technologically driven disruptions in FSCs will affect the operational efficiency of firms. Further, our study uses a theoretical framework to facilitate the adoption of technology in FPIs. These technology enablers have been determined by reviewing past studies on technology adoption; expert opinions in IT, food processing, and supply chain domain, and academicians. This study is a first attempt to identify the enablers of technology in FPIs which will boost resilience, integration, and transparency and therefore enhance the operational efficiency of these firms.

\subsection{Operational efficiency}

Extant studies define operational efficiency in terms of the overall processes of organizations leading to favorable effects on productivity, asset management, inventory control, flexibility and agility of business operations, delivery times, and coordination [Cheng et al., 2018; Essuman et al., 2020]. Sullivan et al. (2002) explain operational efficiency in supply chains as representing cost-effectiveness in preventive, predictive, and reliable technologies to ensure reliability, safety, and system efficiency. Various contexts like total quality management (TQM), just-in-time (JIT) approach have been used to evaluate the level of operational efficiency, which can further be used as a measure to assess and evaluate a firm's performance. In our study, we have defined operational efficiency in terms of resilience, transparency, and integration in food supply chains.

\subsubsection{Resilience}

Attributable to the seminal work of Christopher \& Peck (2004) and Sheffi (2005), supply chain resilience addresses the ability of supply chains to endure unavoidable risks and disruptions [Wang et al., 2013]. Organizational supply chain resilience is the capacity to have control over desirable functions under unexpected situations [Weick et al., 1999; Gunasekaran et al., 
2015]. Other scholars like Hamel \& Valikangas (2004) have emphasized that the concept of supply chain resilience should be extended to deriving sustainable competitive advantage while the definition by Fiksel et al. (2015) includes firms' capacity to grow in turbulent times. Thus resilience can be understood in terms of vulnerability and adaptive capacity of businesses in tough times. In a recent study, Gu et al. (2020) have found the positive effect of technology implementation on supply chain resilience. This result has also been established in other studies conducted by Dubey et al. (2019); Wamba et al. (2020); Galbraith (1974); Huo et al. (2015) and Yu et al. (2017).

\subsubsection{Transparency}

Extant literature has explained supply chain transparency as readily available information to all stakeholders involved [Awaysheh, Klassen, 2010; Mol, 2014]. This involves sharing information on current orders, production and inventory status, plans and forecasts, transport and distribution with supply chain partners [Francisco, Swanson, 2018; Sodhi, Tang, 2019; Gardner et al., 2019]. It has also been studied in the context of traceability [Doorey, 2011; Germani et al., 2015] and sustainability [Cramer, 2008; Kashmanian, 2017]. Studies have explored the benefits of enhanced supply chain transparency. These include generating greater trust [Montecchi et al., 2019], influencing consumer purchase intentions positively [Bhaduri, Ha-Brookshire, 2011; Nisar, Prabhakar, 2017], improving the firm's legitimacy [Carter, Rogers, 2008]. Implementation of disruptive technologies has a high potential for alleviating transparency [Venkatesh et al., 2020].

\subsubsection{Integration}

Supply chain integration refers to effective linkages established between various partners involved in a supply chain [Vieira et al., 2020; Van der Vaart, van Donk, 2008; Danese, Bortolotti, 2014]. This integration promotes coordination and collaboration [Jia et al., 2020; Xue et al., 2005; Zeng et al., 2017]. Since the scope of integration varies across businesses and firms, scholars [Mentzer et al., 2001; Jahre, Fabbe-Costes, 2005] have differentiated between limited dyadic upstream (company and suppliers), limited dyadic downstream (company and customers), limited dyadic (company, customers and suppliers- separate upstream and downstream), limited triadic (company, customers and suppliers- interdependent) and extended (more than three stakeholders) supply chains. Integrated supply chains bring strategic and operational benefits to organizations [Jajja et al., 2018; Yu, Huo, 2018; Peng et al., 2020]. Empirical studies have advocated that the higher is the level of integration, the better it is for stakeholders involved [Munir et al., 2020; Gimenez, Ventura, 2005]. Few studies have linked the level of supply chain integration with a firm's performance and have found a positive relationship between them [Power, 2005]. Recent studies have explored the impact of the technological intervention on supply chain integration [Büyüközkan, Göçer, 2018; Kamble et al., 2020; Ageron et al., 2020].

\subsection{Enablers of technology adoption}

For AI adoption, technological feasibility in terms of determining the economic viability and providing relevant inputs is crucial [Francisco, Swanson, 2018; Van Royen et al., 2015]. Ag- 
rawal et al. (2018) and Rikhardsson \& Dull (2016) have identified technological sophistication as explaining the existing technological use in an organisation and the available state of technical know-how. Data quality and integrity is another factor that would overcome the existing vulnerabilities in the supply chain and can facilitate AI implementation [Khan, Salah, 2018; Wong et al., 2020; Grover et al., 2019]. Another crucial AI enabler is interoperability as it facilitates smooth communication and integration between various partners in the supply chain [Galvez et al., 2018; Borgogno, Colangelo, 2019]. Extant studies have also emphasized on perceived benefits of technology usage, as it can drive its adoption [Dwivedi et al., 2019; Kamble et al., 2019; Ray et al., 2019].

\subsection{Technology adoption and operational efficiency}

Extant studies have shown that it is possible to enhance firms' operational efficiency via technological intervention [Ahuja et al., 2020; Ain et al., 2019; Nam et al., 2019]. Since a potentially disruptive technology is capable of overcoming supply chain barriers, it can boost a firm's performance and efficiency in carrying out various functions [Saberi et al., 2019; Molina-Morales et al., 2019]. Similarly, studies have shown that due to the ripple effects, using outdated and inefficient technology can hamper business efficiency, effectiveness, and performance [Yeniyurt et al., 2019; Dowlatshahi, Cao, 2006]. In the context of FPIs, studies have shown that technology-related problems have an adverse impact on a firm's performance [Compton et al., 2018; Kamilaris et al., 2019; Singh et al., 2019]. Such problems can also lead to a decline in firm's market share and profits and therefore a loss of competitiveness in the marketplace.

\section{Research methodology}

This section incorporates the research design of the study, including questionnaire designing, target population, and sampling methods used to test the given framework. The sampling frame of the study was IT professionals, supply chain professionals, managers of food processing companies, and academicians working in this domain. The respondents were contacted from all parts of India so that we can have a representation of each region. The questionnaire was circulated to more than 500 respondents through mails and personal visits. A cover letter was attached to the questionnaire so that the purpose of the research was made clear in the minds of the respondents. Out of the people contacted, 341 respondents sent back the completed questionnaires which were later analysed. Respondents were asked to rate the items such as "I believe that application of AI helps in effectively managing supplier relationships" and "I believe that application of AI makes it easier to consistently communicating the company's key initiatives to the stakeholders". The respondents were asked to rate them between 1 to 7 where 1 stands for strongly disagree and 7 stands for strongly agree. Data were collected on 7 points Likert scale. Reverse coding was done on negative wording items. The questionnaire was closeended and there were no right or wrong answers. Among the respondents 63 per cent of them were males and the remaining were females. Out of 341 respondents, 32 per cent were from North India, 27 per cent from South, 23 per cent were from west India, and the rest 18 per cent were from Eastern India. 


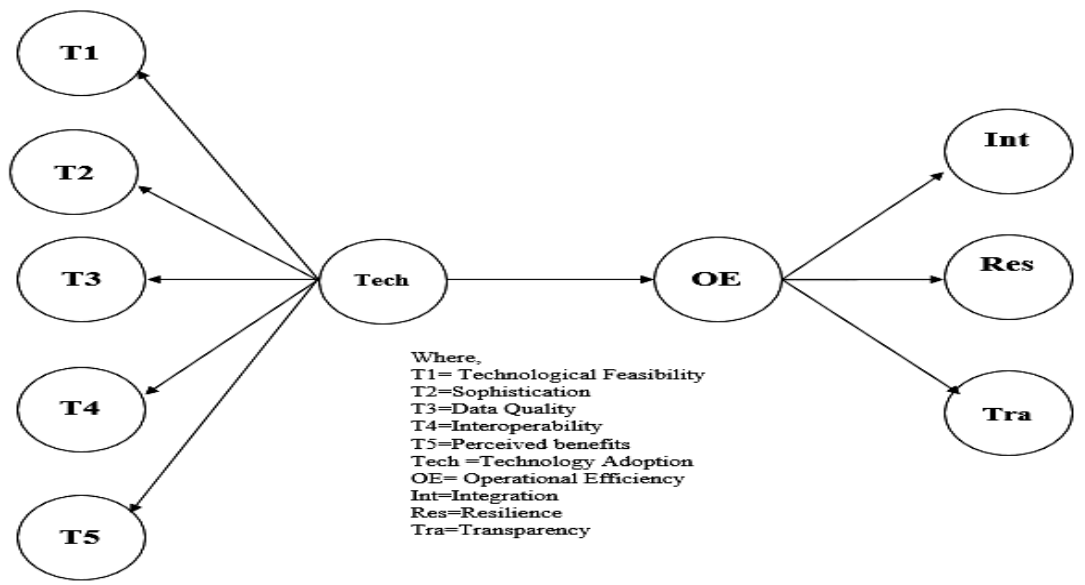

Fig. 1. Proposed research framework

Source: Authors'.

\subsection{Measures}

To test the above relationship between technology adoption and operational efficiency, higher-order reflective constructs were taken for analysis. Technology adoption is the second-order construct comprising of 5 zero-order constructs of technological feasibility, sophistication, data quality, interoperability, and perceived benefits. Whereas operational efficiency is a higherorder construct comprising integration, transparency, and resilience. All these constructs were taken from the literature (as mentioned in section II) and measured on a 7 point Likert scale. The questionnaire was close-ended and there were no right or wrong answers.

For promoting social desirability, the questionnaire had a neutral choice so that response bias can be eliminated [Nederhof, 1985]. The participation was voluntary and anonymous. The respondents filed the questionnaire in their relaxed environment and sufficient time was provided to fill and return the questionnaire. It was carefully worded to avoid the problem of extreme response biases [Meisenberg, Williams, 2008]. The content validity was established by sharing the questionnaire with experts and incorporating their views and comments in it. It led to the refining of the items of the scale helped in reaching face validity. After the questionnaire was modified, it was pilot tested on 18 respondents, and the reliability indicated by Cronbach Alpha was found to be more than 0.8 for all constructs. Statistical methods and procedures were undertaken to make the questionnaire free from common method bias [Podsakoff et al., 2003].

\subsection{Tools used}

The application of Structural Equation Modelling (SEM) is popular in several fields of knowledge including operation research [Kaynak et al., 2015; Kaufmann, Gaeckler, 2015]. The variance-based approach is also known as partial least square (PLS) [Hair et al., 2014). It is also known as PLS-SEM. The method is a prediction oriented approach whose objective is to maximize the explained variance of the dependent variable. The alternate method of covariance-based 
modeling emphasizes reproducing the theoretical covariance matrix [Hair et al., 2014]. Some scholars have also used PLS-SEM for confirmatory analysis [Chin, 2010; Henseler et al., 2014]. This method is suitable for complex and large models and incorporates both reflective as well as formative models [Hair et al., 2014]. The model has fewer restrictions on assumptions about data and can work even with smaller samples [Henseler et al., 2014] The study uses higher-order constructs which makes the path model more parsimonious and allows for additional content comprised of the specific constructs [Hair et al., 2017]. Most of the research is focused on the second-order construct that is reflective in nature.

\section{Results, discussion, and implications}

\subsection{Results}

\subsubsection{Common method variance}

The problem of common method variance was addressed with Harmon single factor test. The test was conducted in SPSS23 software. A single factor or general factor did not account for the majority of variance in factor analysis. So the analysis was free from the above-mentioned problem [Podsakoff et al., 2003].

\subsubsection{PLS-SEM model}

The model has two parts, the outer model and the inner model. The outer model is assessed with the help of the following tables. Composite reliability is mentioned in table 1 is greater than the prescribed value of 0.7 [Hair et al., 2014]. AVE is used to reflect convergent validity. The cutoff value of AVE is 0.50 [Hair et al., 2006]. As can be seen from table 1 all the values are above 0.50 .

Table 1.

Reliability

\begin{tabular}{l|c|c|c|c}
\hline & $\begin{array}{c}\text { Cronbach's } \\
\text { Alpha }\end{array}$ & Rho_A & $\begin{array}{c}\text { Composite } \\
\text { Reliability }\end{array}$ & $\begin{array}{c}\text { Average } \\
\text { Variance } \\
\text { Extracted (AVE) }\end{array}$ \\
\hline Data quality and integrity & 0.882 & 0.883 & 0.883 & 0.715 \\
Integration & 0.855 & 0.856 & 0.855 & 0.542 \\
Interoperability & 0.897 & 0.897 & 0.897 & 0.744 \\
Perceived benefits & 0.893 & 0.896 & 0.893 & 0.737 \\
Resilience & 0.871 & 0.875 & 0.871 & 0.576 \\
Sophistication & 0.877 & 0.878 & 0.877 & 0.588 \\
Technological feasibility & 0.885 & 0.889 & 0.886 & 0.722 \\
Transparency & 0.883 & 0.884 & 0.883 & 0.601 \\
\hline \hline
\end{tabular}

Source: Authors'. 
Fornell Larcker criteria [Fornell, Larcker, 1981] and cross loadings are generally used for measuring discriminant validity. Recently in 2015, Henseler et al. proposed the new Heterotrait - momotrait ratio of correlation measure to assess discriminant validity. It is calculated by finding the average of heterotrait homomethod correlation and divided by the average of monotrait heteromethod correlation. This method is considered superior and the value should be less than 0.85 [Henseler et al., 2015]. As can be seen from table 2, all the values are less than 0.85 and are thereby fulfilling the criterion.

Table 2 .

Discriminant validity

\begin{tabular}{|c|c|c|c|c|c|c|c|c|}
\hline & $\begin{array}{c}\text { Data } \\
\text { quality } \\
\text { and } \\
\text { integrity }\end{array}$ & $\begin{array}{l}\text { Integra- } \\
\text { tion }\end{array}$ & $\begin{array}{c}\text { Intero- } \\
\text { perability }\end{array}$ & $\begin{array}{c}\text { Perceived } \\
\text { benefits }\end{array}$ & Resilience & $\begin{array}{l}\text { Sophisti- } \\
\text { cation }\end{array}$ & $\begin{array}{c}\text { Techno- } \\
\text { logical } \\
\text { feasibility }\end{array}$ & $\begin{array}{c}\text { Transpa- } \\
\text { rency }\end{array}$ \\
\hline \multicolumn{9}{|l|}{$\begin{array}{l}\text { Data quality } \\
\text { and integrity }\end{array}$} \\
\hline Integration & 0.275 & & & & & & & \\
\hline Interoperability & 0.469 & 0.245 & & & & & & \\
\hline $\begin{array}{l}\text { Perceived } \\
\text { benefits }\end{array}$ & 0.513 & 0.248 & 0.461 & & & & & \\
\hline Resilience & 0.111 & 0.468 & 0.138 & 0.093 & & & & \\
\hline Sophistication & 0.419 & 0.213 & 0.511 & 0.434 & 0.172 & & & \\
\hline $\begin{array}{l}\text { Technological } \\
\text { feasibility }\end{array}$ & 0.503 & 0.218 & 0.47 & 0.66 & 0.043 & 0.527 & & \\
\hline Transparency & 0.203 & 0.339 & 0.217 & 0.233 & 0.359 & 0.186 & 0.23 & \\
\hline
\end{tabular}

Source: Authors'.

The inner model was used to test the relationship between technology adoption and operational efficiency. The significance of the path coefficients was established with the help of the bootstrapping method for 5000 samples ( 2 tailed). It is a non-parametric procedure to assess the significance of the structure of the model. The below-mentioned hypothesis was tested and found to be significant (Table 3 ).

Table 3.

Hypothesis testing

\begin{tabular}{lcc}
\hline \multicolumn{1}{c|}{ Hypothesis Tested } & P Values & Decision \\
\hline Operational Efficiency -> Integration & 0.0000 & Accepted \\
Operational Efficiency -> Resilience & 0.0000 & Accepted \\
Operational Efficiency -> Transparency & 0.0000 & Accepted \\
Technology -> Data quality and integrity & 0.0000 & Accepted \\
Technology -> Interoperability & 0.0000 & Accepted \\
Technology -> Operational Efficiency & 0.0000 & Accepted \\
Technology -> Perceived benefits & 0.0000 & Accepted \\
Technology -> Sophistication & 0.0000 & Accepted \\
Technology -> Technological feasibility & 0.0000 & Accepted \\
\hline \hline
\end{tabular}

Source: Authors'. 
All 9 hypotheses of our study have been accepted. All the five zero-order constructs measure technology adoption and all 3 zero-order constructs (integration, transparency, and resilience) measure operational efficiency. We are more interested in understanding the path between technology adoption and operational efficiency. It can be concluded that technology adoption in the food processing industry will lead to enhanced operational efficiency thereby improving the resilience of the industry. The $\mathrm{R}$ square value suggests that it has adequate predictive power. Thus, the implementation of AI will promote transparency. It will improve the flow of information which will add to backward and forward integration of the supply chain. The method of blindfolding was applied to cross-validate the predictive relevance of the inner model. $\mathrm{Q}^{2}$ was calculated with the omission distance of 7 (default). Q square was greater than zero stating endogenous construct has predictive relevance.

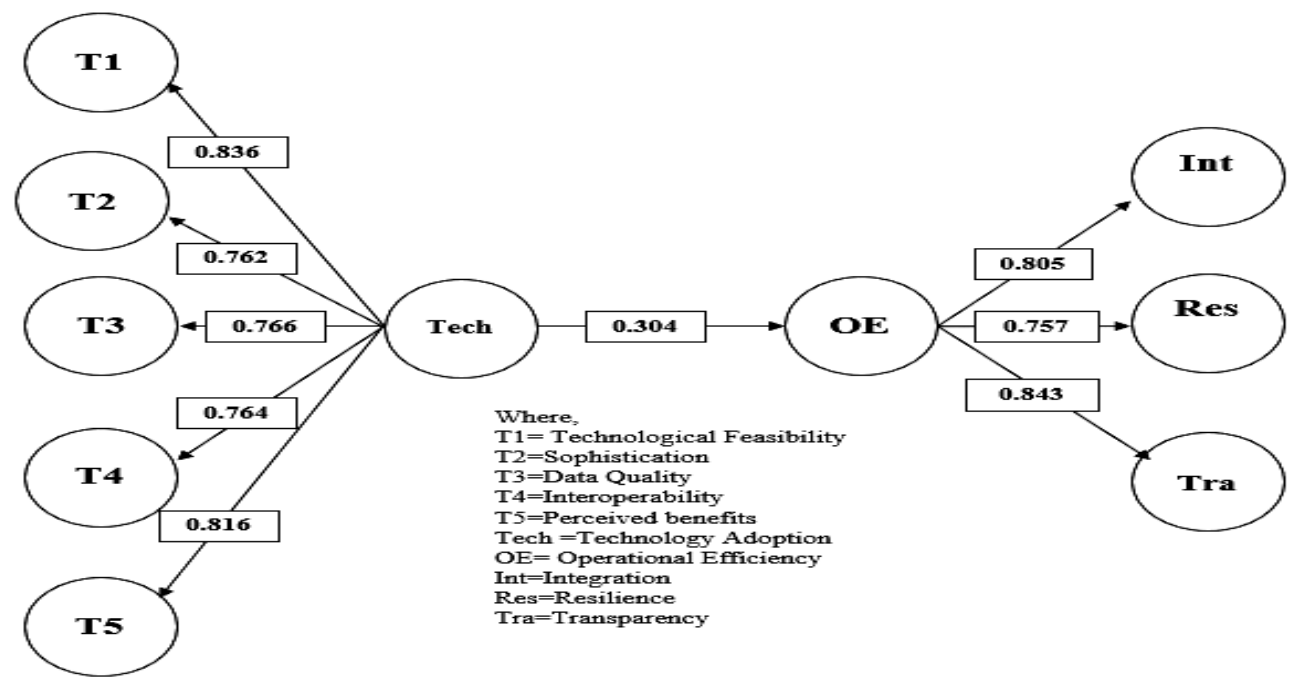

Fig. 2. Final model

The study highlights the growing importance of technology in the food processing domain. The external environment is changing drastically and with the advent of new technologies and innovation, all companies need to bridge the gap in terms of the skill set required to switch to these technologies. For maximizing efficiency, it is important to adopt these technologies which bring with them higher productivity and optimal resource allocation.

\subsection{Discussion}

This study has two broad outcomes. In the first place, the study has identified the enablers of AI technology in FPIs. Despite India's commendable position in global agricultural production, foreign exchange generation via exports of agricultural and processed foods, there is little attention paid towards overcoming the existing obstacles faced by SMEs in Indian FPIs through the interface of technology. An intensive literature review of existing studies in AI domain has revealed technological feasibility, sophistication, data quality, interoperability and perceived bene- 
fits as crucial factors in technological adoption in the processing stage of FSC. In our study, technological feasibility has emerged to be the most important factor as it explains the intention and availability of resources to undertake technological innovation. These resources can be in the form of capital, human and technical know-how. Technological sophistication is also crucial as it addresses issues pertaining to technological feasibility and establishes the capability of these firms to handle issues pertaining to data security and privacy. Studies in past have also established the prominence of data quality [Li et al., 2020] which has been supported by the findings of our study. Data quality indicates usability which is explained in terms of data reliability and trustworthiness. Interoperability is vital as it processes the received data and facilitates smooth communication between different stakeholders, which is one of the desired outcome of AI adoption. Perceived benefits of AI adoption by SMEs involved in FPIs would motivate other firms to undertake technology adoption and reap its benefits.

In the second place, the study establishes the relationship between AI adoption and operational efficiency of firms in FPIs. Here, operational efficiency has been defined in terms of resilience, integration, and transparency. The authors have found a positive association between technology adoption and improved operational efficiency. The result of the study shows that technology can contribute to enhancing supply chain resilience, which can improve supply chain performance. Another theoretical contribution of our work is that AI can help overcome improper coordination between partners and activities and can boost supply chain integration. Thus, by employing the technological framework, our study better explains the way to build a seamless supply chain network which would aid firms in Indian FPIs to establish their competitive advantage. Our study, therefore, adds to the existing literature on the food supply chain by highlighting the role of AI implementation in enhancing operational efficiency and business performance of FPIs.

\subsection{Implications}

\subsubsection{Managerial implications}

This study would enable managers in the food processing industry to develop a comprehensive understanding of the role of disruptive technologies in food supply chains. Supply chain transparency, executed through technology intervention, can empower customers to share, discuss, and exchange information about products and services. This can also be used as a platform to communicate effectively with stakeholders in creating awareness, soliciting a response, undergoing modifications, and transferring it back. This would generate transparency and trust, which is a useful tool for practicing managers. Companies can also use it as a differentiator and position it as a marketing tool or develop it as a competitive strategy in their businesses. By using the findings of our study, businesses can expect higher sales and revenue for their companies. We also suggest firms display their business transparency on digital communication platforms for example mobile apps, which would enhance communication with external partners in the supply chain. AI technology can help managers indulge in collaborative planning and can thus make supply chain collaboration more effective and resilient.

Further, as supply chain professions are aware of the problems and the sources of these problems in FPI, this study will enable them to develop technological solutions to overcome these problems. Implementation of disruptive technologies would lead supply chain manage- 
ment in FPI to progress from supporting decisions to a delegating role and further to the prediction mode. Digital supply chains would facilitate managers to innovate and find new business models with better integration amongst partners involved. The study also stresses the importance of keeping abreast with technological developments and their different facets, which is much needed for maintaining competitiveness and sustainability in a dynamic market place. This can emerge as a mantra for enhancing operational efficiency and business performance.

\subsubsection{Policy implications}

Based on the research findings of our study, it is suggested that technological feasibility, sophistication, data quality and integrity, interoperability, and perceived benefits can enable technology adoption in Indian FPI and can therefore enhance the efficiency of these firms. These findings, however, pose challenges for policymakers as fostering and harnessing resilience, transparency, and integration in the food supply chain while dealing with different partners of the supply chain would be intricate. At the foremost, it calls for creating an enabling environment, comprising of macro-economic and micro-institutional factors for technology adoption and diffusion by the firms. Since Indian FPI is captured predominantly by SMEs, which are plagued by financial constraints, government finance, driven by various technology transfer programs can offer a solution. Different modalities like grants, loans, and public-private partnerships can help achieve this. Additionally, various training programs, seminars, certification programs, industry deliberations can extend assistance to SMEs for upgrading the existing technology and realize industry potential. Policymakers should also focus on the existing uncertain regulatory and complex legal framework. Clarity on these parameters would instill confidence amongst businesses. This study also suggests that policymakers should facilitate an extensive system of infomediaries, which would enhance supply chain transparency.

\subsubsection{Social implications}

The findings of our study have strong social impactions. Implementation of ICT tools would alter the nature of jobs in food supply chains. In order to understand and execute the contract-to-real-world interfaces, a thorough understanding of technology and its features would be a must, and acquisitions of new skills would be a prerequisite for this. Apart from the routine handling, it would also call for specialized experts in planning, developing, operating, integrating, and controlling digital supply chains. New job roles like legal supply chain counseling and auditing will also emerge. All of this would require a specialized workforce. From the companies' perspective, this would entail modifications in their recruitment drives and reskilling the existing workforce. As skills and knowledge drive economic growth, driven to reinvigorate and re-energizing the domestic workforce, the National Skill Development Mission has an institutional mechanism to scale up training efforts to meet employers' demands and expectations. Ministry of Information Technology is running large scale skill training programs. Such concerted efforts will instill confidence, enhance productivity, and living standards of the population. It would also generate a conducive social environment for society at large. 


\section{Conclusion}

The findings of this study indicate that technology usage by SMEs in Indian FPI is in the nascent stage. The study construed the five most significant enablers for AI technology, viz. technological feasibility, sophistication, data quality, and integrity, interoperability, and perceived benefits. These were extracted by reviewing the literature on technology adoption and obtaining expert opinions of academicians and professionals in IT, food processing, and supply chain domains. The study indicates that the identification of these technology enablers would enable supply chain professionals to focus and assign more importance to these aspects of technology while initiating technology adoption. This would boost resilience, integration, transparency, and will impart robustness in food supply chains.

This study is based on the responses collected from academicians and experts in IT, supply chain, and food processing domain. Since these opinions may be biased or ambiguous, future studies can apply other techniques of reducing this uncertainty. Further, future research can explore other technological dimensions and different parameters of measuring operational efficiency in their conceptual frameworks, then what has been used in our study. Also, the applicability of this study can be extended by replicating this framework to other industries. Furthermore, it may also be useful to extend respondents to include employees in the food supply chain across countries with a strong agriculture sector.

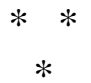

\section{References}

Ageron B., Bentahar O., Gunasekaran A. (2020, July). Digital Supply Chain: Challenges and Future Directions. Supply Chain Forum: An International Journal, Taylor \& Francis, 21, 3, pp. 133-138.

Agrawal T.K., Sharma A., Kumar V. (2018) Blockchain-based Secured Traceability System for Textile and Clothing Supply Chain. Artificial Intelligence for Fashion Industry in the Big Data Era (eds. S. Thomassey, X. Zeng), Singapore: Springer, pp. 197-208.

Ahi P., Jaber M.Y., Searcy C. (2016) A Comprehensive Multidimensional Framework for Assessing the Performance of Sustainable Supply Chains. Applied Mathematical Modelling, 40, 23-24, pp. 10153-10166.

Ahuja R., Sawhney A., Jain M., Arif M., Rakshit S. (2020) Factors Influencing BIM Adoption in Emerging Markets - The Case of India. International Journal of Construction Management, 20, 1, pp. 65-76.

Ain N., Vaia G., DeLone W.H., Waheed M. (2019) Two Decades of Research on Business Intelligence System Adoption, Utilization and Success - A Systematic Literature Review. Decision Support Systems, 125. Doi:10.1016/j.dss.2019.113113.

Ali S.M., Moktadir M.A., Kabir G., Chakma J., Rumi M.J.U., Islam M.T. (2019) Framework for Evaluating Risks in Food Supply Chain: Implications in Food Wastage Reduction. Journal of Cleaner Production, 228, pp. 786-800.

Augustin M.A., Riley M., Stockmann R., Bennett L., Kahl A., Lockett T., ... \& Cobiac L. (2016) Role of Food Processing in Food and Nutrition Security. Trends in Food Science \& Technology, 56, pp. 115-125.

Awaysheh A., Klassen R.D. (2010) The Impact of Supply Chain Structure on the Use of Supplier Socially Responsible Practices. International Journal of Operations \& Production Management, 30, 12, pp. 12461268. 
Balaji M., Arshinder K. (2016) Modeling the Causes of Food Wastage in Indian Perishable Food Supply Chain. Resources, Conservation and Recycling, 114, pp. 153-167.

Baryannis G., Validi S., Dani S., Antoniou G. (2019) Supply Chain Risk Management and Artificial Intelligence: State of the Art and Future Research Directions. International Journal of Production Research, 57, pp. 2179-2202.

Bechtsis D., Tsolakis N., Vlachos D., Iakovou E. (2017) Sustainable Supply Chain Management in the Digitalisation Era: The Impact of Automated Guided Vehicles. Journal of Cleaner Production, 142, pp. 39703984.

Behnke K., Janssen M.F.W.H.A. (2020) Boundary Conditions for Traceability in Food Supply Chains Using Blockchain Technology. International Journal of Information Management, 52, 101969.

Bevilacqua M., Ciarapica F.E., Marcucci G., Mazzuto G. (2020) Fuzzy Cognitive Maps Approach for Analysing the Domino Effect Of Factors Affecting Supply Chain Resilience: A Fashion Industry Case Study. International Journal of Production Research, 58, 20, pp. 6370-6398.

Bhaduri G., Ha-Brookshire J.E. (2011) Do Transparent Business Practices Pay? Exploration of Transparency and Consumer Purchase Intention. Clothing \& Textiles Research Journal, 29, 2, pp. 135-149.

Borgogno O., Colangelo G. (2019) Data Sharing and Interoperability: Fostering Innovation and Competition Through APIs. Computer Law \& Security Review, 35, 5, 105314.

Büyüközkan G., Göçer F. (2018) Digital Supply Chain: Literature Review and a Proposed Framework for Future Research. Computers in Industry, 97, pp. 157-177.

Carter C.R., Rogers D.S. (2008) A Framework of Sustainable Supply Chain Management: Moving Toward New Theory. International Journal of Physical Distribution \& Logistics Management, 38, 5, pp. 360-387.

Chandrasekaran M., Ranganathan R. (2017) Modelling and Optimisation of Indian Traditional Agriculture Supply Chain to Reduce Post-Harvest Loss and CO2 Emission. Industrial Management \& Data Systems, 117, 9, pp. 1817-1841.

Cheng Q., Goh B.W., Kim J.B. (2018) Internal Control and Operational Efficiency. Contemporary Accounting Research, 35, 2, pp. 1102-1139.

Chin W.W. (2010) How to Write Up and Report PLS Analyses. Handbook of Partial Least Squares (eds. V. Esposito Vinzi, W.W. Chin, J. Henseler, H. Wangds), Berlin, Heidelberg: Springer Berlin Heidelberg, pp. 655-690.

Christopher M., Peck H. (2004) Building the Resilient Supply Chain. International Journal of Logistics Management, 15, 2, pp. 1-14.

CII (2019) Available at: http://face-cii.in/sites/default/files/food_processing_report_2019.pdf (accessed 25 October 2020)

Compton M., Willis S., Rezaie B., Humes K. (2018) Food Processing Industry Energy and Water Consumption in the Pacific Northwest. Innovative Food Science \& Emerging Technologies, 47, pp. 371-383.

Craighead C.W., Blackhurst J., Rungtusanatham M.J., Handfield R.B. (2007) The Severity of Supply Chain Disruptions: Design Characteristics and Mitigation Capabilities. Decision Sciences, 38, 1, pp. 131-156. Doi:10.1111/j.1540-5915.2007.00151.x

Cramer J.M. (2008) Organising Corporate Social Responsibility in International Product Chains. Journal of Cleaner Production, 16, 3, pp. 395-400.

Danese P., Bortolotti T. (2014) Supply Chain Integration Patterns and Operational Performance: A Plant-Level Survey-Based Analysis. International Journal of Production Research, 52, 23, pp. 7062-7083.

Doorey D.J. (2011) The Transparent Supply Chain: From Resistance to Implementation at Nike and Levi-Strauss. Journal of Business Ethics, 103, 4, pp. 587-603.

Dowlatshahi S., Cao Q. (2006) The Relationships among Virtual Enterprise, Information Technology, and Business Performance in Agile Manufacturing: An Industry Perspective. European Journal of Operational Research, 174, 2, pp. 835-860.

Dubey R., Gunasekaran A., Childe S.J., Fosso Wamba S., Roubaud D., Foropon C. (2019) Empirical Investigation of Data Analytics Capability and Organizational Flexibility as Complements to Supply Chain Resilience. International Journal of Production Research, 59, 1, pp. 110-128. 
Dwivedi Y.K., Hughes L., Ismagilova E., Aarts G., Coombs C., Crick T. et al. (2019) Artificial Intelligence (AI): Multidisciplinary Perspectives on Emerging Challenges, Opportunities, and Agenda for Research, Practice and Policy. International Journal of Information Management, 57, 101994.

Essuman D., Boso N., Annan J. (2020) Operational Resilience, Disruption, and Efficiency: Conceptual and Empirical Analyses. International Journal of Production Economics, 229, 107762.

FAO (2019) Available at: http://www.fao.org/india/fao-in-india/india-at-a-glance/ar/\#: :text= India $\% 20$ is $\% 20$ the $\% 20$ world's $\% 20$ largest,poultry $\% 2 \mathrm{C} \% 20$ livestock $\% 20$ and $\% 20$ plantation $\% 20 \mathrm{crops}$ (accessed on 22 October 2020).

Fiksel J., Polyviou M., Croxton K.L., Pettit T.J. (2015) From Risk to Resilience: Learning to Deal with Disruption. MIT Sloan Management Review, 56, 2, pp. 79-86.

Fornell C., Larcker D.F. (1981) Evaluating Structural Equation Models with Unobservable Variables and Measurement Error. Journal of Marketing Research, 18, 1, pp. 39-50.

Francisco K., Swanson D. (2018) The Supply Chain Has No Clothes: Technology Adoption of Blockchain for Supply Chain Transparency. Logistics, 2, 1, 2.

Galbraith J.R. (1974) Organization Design: An Information Processing View. Interfaces, 4, 3, pp. 28-36.

Galvez J.F., Mejuto J.C., Simal-Gandara J. (2018) Future Challenges on the Use of Blockchain for Food Traceability Analysis. TrAC Trends in Analytical Chemistry, 107, pp. 222-232.

Gardner T.A., Benzie M., Börner J., Dawkins E., Fick S., Garrett R., ... \& Mardas N. (2019). Transparency and Sustainability in Global Commodity Supply Chains. World Development, 121, pp. 163-177.

Germani M., Mandolini M., Marconi M., Marilungo E., Papetti A. (2015) A System to Increase the Sustainability and Traceability of Supply Chains. Procedia CIRP, 29, pp. 227-232.

Gimenez C., Ventura E. (2005) Logistics-production, Logistics-marketing and External Integration. International Journal of Operations \& Production Management, 25, 1, pp. 20-38.

Grand Thornton - Assocham (2017) Food Processing Sector - Challenges and Growth Enablers. New Delhi. Available at: https://www.grantthornton.in/globalassets/1.-member-irms/india/assets/pdfs/ food_processing_sector.pdf

Grover P., Kar A.K., Janssen M., Ilavarasan P.V. (2019) Perceived Usefulness, Ease of Use and User Acceptance of Blockchain Technology for Digital Transactions-Insights from User-generated Content on Twitter. Enterprise Information Systems, 13, 6, pp. 771-800.

Gu M., Yang L., Huo B. (2020) The Impact of Information Technology Usage on Supply Chain Resilience and Performance: An Ambidexterous View. International Journal of Production Economics, 232, 107956. Gunarathne A.N., Navaratne D.G., Pakianathan A.E. (2018) Sustainable Food Supply Chain Management: An Integrated Framework and Practical Perspectives. Ch. 11. Innovative Solutions for Sustainable Supply Chains. Cham: Springer, pp. 289-315.

Gunasekaran A., Subramanian N., Rahman S. (2015) Supply Chain Resilience: Role of Complexities and Strategies. International Journal of Production Research, 53, 22, pp. 6809-6819. http://dx.doi.org/10.1080/ 00207543.2015.1093667

Hair J.F., Black W.C., Babin B.J., Anderson R.E., Tatham R.L. (2006) Multivariate Data Analysis, $6^{\text {th }}$ ed., Pearson Prentice Hall.

Hair J.F., Sarstedt M., Hopkins L., Kuppelwieser V.G. (2014) Partial Least Squares Structural Equation Modeling (PLS-SEM): An Emerging Tool in Business Research. European Business Review, 26, 2, pp. 106121.

Haleem A., Khan S., Khan M.I. (2019) Traceability Implementation in Food Supply Chain: A GreyDEMATEL Approach. Information Processing in Agriculture, 6, 3, pp. 335-348.

Halley A., Beaulieu M. (2010) A Multidimensional Analysis of Supply Chain Integration in Canadian Manufacturing. Canadian Journal of Administrative Sciences/Revue Canadienne des Sciences de l'Administration, 27, 2, pp. 174-187.

Hamel G., Valikangas L. (2004) The Quest for Resilience. Harvard Business Review, 81, 9, pp. 52-63.

Henseler J., Hubona G., Ray P.A. (2016) Using PLS Path Modeling in New Technology Research: Updated Guidelines. Industrial Management \& Data Systems, 116, 1, pp. 2-20. 
Henseler J., Dijkstra T.K., Sarstedt M., Ringle C.M., Diamantopoulos A., Straub D.W., Ketchen D.J.Jr, Hair J.F., Hult G.T.M., Calantone R.J. (2014) Common Beliefs and Reality about PLS, Organizational Research Methods, 17, 2, pp. 182-209. Available at: https://doi.org/10.1177/ 1094428114526928.

Henseler J., Ringle C.M., Sarstedt M. (2015) A New Criterion for Assessing Discriminant Validity in Variance-Based Structural Equation Modeling. Journal of the Academy of Marketing Science, 43, 1, pp. 115-135.

Hsiao H.I., Kemp R.G.M., van der Vorst J.G.A.J., Omta S.O. (2010) A Classification of Logistic Outsourcing Levels and their Impact on Service Performance: Evidence from the Food Processing Industry. International Journal of Production Economics, 124, 1, pp. 75-86.

Huo B., Wang Z., Tian Y. (2016) The Impact of Justice on Collaborative and Opportunistic Behaviors in Supply Chain Relationships. International Journal of Production Economics, 177, pp. 12-23.

Huo B., Zhang C., Zhao X. (2015) The Effect of IT and Relationship Commitment on Supply Chain Coordination: A Contingency and Configuration Approach. Information \& Management, 52, 6, pp. 728-740. Jahre M., Fabbe-Costes N. (2005) Adaptation and Adaptability in Logistics Networks. International Journal of Logistics Research and Applications, 8, 2, pp. 143-157.

Jajja M.S.S., Chatha K.A., Farooq S. (2018) Impact of Supply Chain Risk on Agility Performance: Mediating Role of Supply Chain Integration. International Journal of Production Economics, 205, pp. 118-138. Jia F., Blome C., Sun H., Yang Y., Zhi B. (2020) Towards an Integrated Conceptual Framework of Supply Chain Finance: An Information Processing Perspective. International Journal of Production Economics, 219, pp. 18-30.

Kamble S.S., Gunasekaran A., Sharma R. (2020) Modeling the Blockchain Enabled Traceability in Agriculture Supply Chain. International Journal of Information Management, 52, 101967.

Kamble S., Gunasekaran A., Arha H. (2019) Understanding the Blockchain Technology Adoption in Supply Chains-Indian Context. International Journal of Production Research, 57, 7, pp. 2009-2033.

Kamilaris A., Fonts A., Prenafeta-Boldú F.X. (2019) The Rise of Blockchain Technology in Agriculture and Food Supply Chains. Trends in Food Science \& Technology, 91, pp. 640-652.

Kashmanian R.M. (2017) Building Greater Transparency in Supply Chains to Advance Sustainability. Environmental Quality Management, 26, 3, pp. 73-104.

Kaufmann L., Gaeckler J. (2015) A Structured Review of Partial Least Squares in Supply Chain Management Research. Journal of Purchasing and Supply Management, 21, 4, pp. 259-272.

Kaynak R., Sert T., Sert G., Akyuz B. (2015) Supply Chain Unethical Behaviors and Continuity of Relationship: Using the PLS Approach for Testing Moderation Effects of Inter-organizational Justice. International Journal of Production Economics, 162, pp. 83-91.

Khan M.A., Salah K. (2018) IoT Security: Review, Blockchain Solutions, and Open Challenges. Future Generation Computer Systems, 82, pp. 395-411.

Kittipanya-Ngam P., Tan K.H. (2020) A Framework for Food Supply Chain Digitalization: Lessons from Thailand. Production Planning \& Control, 31, 2-3, pp. 158-172.

Köhler S., Pizzol M. (2020) Technology Assessment of Blockchain-Based Technologies in the Food Supply Chain. Journal of Cleaner Production, 269, 122193.

Kumar S., Rao P. (2016) Financing Patterns of SMEs in India during 2006 to 2013 - an Empirical Analysis. Journal of Small Business \& Entrepreneurship, 28, 2, pp. 97-131.

Li G., Fan H., Lee P.K., Cheng T.C.E. (2015) Joint Supply Chain Risk Management: An Agency and Collaboration Perspective. International Journal of Production Economics, 164, pp. 83-94.

Li X., Jiang P., Chen T., Luo X., Wen Q. (2020) A Survey on the Security of Blockchain Systems. Future Generation Computer Systems, 107, pp. 841-853.

McKinsey (2018). Available at: https://www.mckinsey.com/ /media/mckinsey/industries/ avanced\%20electronics/our\%20insights/whats\%20ahead $\% 20$ for $\% 20$ food $\% 20$ processing $\% 20$ and $\% 2$ 0handling/mckinsey-on-food-processing-and-handling-ripe-for-disruption.ashx (accessed 20 October 2020).

Mentzer J.T., DeWitt W., Keebler J.S., Min S., Nix N.W., Smith C.D., Zacharia Z.G. (2001) Defining Supply Chain Management. Journal of Business Logistics, 22, 2, pp. 1-25. 
Meisenberg G., Williams A. (2008) Are Acquiescent and Extreme Response Styles Related to Low Intelligence and Education? Personality Individual Differences, 44, 7, pp. 1539-1550. Available at: http://www.sciencedirect.com/science/article/pii/S0191886908000238.

Mezquita Y., González-Briones A., Casado-Vara R., Chamoso P., Prieto J., Corchado J.M. (2019) Blockchain-Based Architecture: A MAS Proposal for Efficient Agri-Food Supply Chains. International Symposium on Ambient Intelligence, Cham: Springer, pp. 89-96.

MOFPI (2019) Available at: https://mofpi.nic.in/sites/default/files/databank.pdf (accessed on 22 October 2020).

Mol A.P. (2015) Transparency and Value Chain Sustainability. Journal of Cleaner Production, 107, pp. 154-161.

Molina-Morales F.X., Martínez-Cháfer L., Valiente-Bordanova D. (2019) Disruptive Technology Adoption, Particularities of Clustered Firms. Entrepreneurship \& Regional Development, 31, 1-2, pp. 62-81.

Montecchi M., Plangger K., Etter M. (2019) It's Real, Trust Me! Establishing Supply Chain Provenance Using Blockchain. Business Horizons, 62, 3, pp. 283-293.

Munir M., Jajja M.S.S., Chatha K.A., Farooq S. (2020) Supply Chain Risk Management and Operational Performance: The Enabling Role of Supply Chain Integration. International Journal of Production Economics, 227, 107667.

Nam D., Lee J., Lee H. (2019) Business Analytics Adoption Process: An Innovation Diffusion Perspective. International Journal of Information Management, 49, pp. 411-423.

Nederhof A. (1985) Methods of Coping with Social Desirability Bias: A Review. European Journal of Social Psychology, 15, 3, pp. 263-280. Available at: https://doi.org/10.1002/ejsp.2420150303

Nisar T.M., Prabhakar G. (2017) What Factors Determine E-Satisfaction and Consumer Spending in E-Commerce Retailing? Journal of Retailing and Consumer Services, 39, pp. 135-144.

Nooraie V., Fathi M., Narenji M., Parast M.M., Pardalos P.M., Stanfield P.M. (2020) A Multi-Objective Model for Risk Mitigating in Supply Chain Design. International Journal of Production Research, 58, 5, pp. 1338-1361.

Peng X., Prybutok V., Xie H. (2020) Integration of Supply Chain Management and Quality Management Within a Quality Focused Organizational Framework. International Journal of Production Research, 58, 2, pp. 448-466.

Podsakoff P.M., MacKenzie S.B., Lee J.Y., Podsakoff N.P. (2003) Common Method Biases in Behavioral Research: A Critical Review of the Literature and Recommended Remedies. Journal of Applied Psychology, 88, 5, pp. 879-903.

Power D. (2005) Supply Chain Management Integration and Implementation: a Literature Review. Supply Chain Management: An International Journal, 10, 4, pp. 252-263.

Rajesh R. (2017) Technological Capabilities and Supply Chain Resilience of Firms: A Relational Analysis Using Total Interpretive Structural Modeling (TISM). Technological Forecasting and Social Change, 118, pp. 161-169.

Ray A., Bala P.K., Dasgupta S.A. (2019) Role of Authenticity and Perceived Benefits of Online Courses on Technology Based Career Choice in India: A Modified Technology Adoption Model Based on Career Theory. International Journal of Information Management, 47, pp. 140-151.

Rikhardsson P., Dull R. (2016) An Exploratory Study of the Adoption, Application and Impacts of Continuous Auditing Technologies in Small Businesses. International Journal of Accounting Information Systems, 20, pp. 26-37.

Schniederjans D.G., Curado C., Khalajhedayati M. (2020) Supply Chain Digitisation Trends: An Integration of Knowledge Management. International Journal of Production Economics, 220, 107439.

Sharma M., Luthra S., Joshi S., Kumar A. (2020) Developing a Framework for Enhancing Survivability of Sustainable Supply Chains During and Post-COVID-19 Pandemic. International Journal of Logistics Research and Applications, pp. 1-21.

Sheffi Y. (2005) The Resilient Enterprise: Overcoming Vulnerability for Competitive Advantage. Cambridge, MA: MIT Press. 
Singh R.K., Luthra S., Mangla S.K., Uniyal S. (2019) Applications of Information and Communication Technology for Sustainable Growth of SMEs in India Food Industry. Resources, Conservation and Recycling, 147, pp. 10-18.

Sodhi M.S., Tang C.S. (2019) Research Opportunities in Supply Chain Transparency. Production and Operations Management, 28, 12, pp. 2946-2959.

Song G., Semakula H.M., Fullana-i-Palmer P. (2018) Chinese Household Food Waste and its' Climatic Burden Driven by Urbanization: A Bayesian Belief Network Modelling for Reduction Possibilities in the Context of Global Efforts. Journal of Cleaner Production, 202, pp. 916-924.

Sullivan G.P., Pugh R., Melendez A.P. (2002) Operations and Maintenance Best Practices -A Guide to Achieving Operational Efficiency (No. PNNL-13890). Richland, WA (US): Pacific Northwest National Lab.

Tapscott D., Tapscott A. (2017) How Blockchain Will Change Organizations. MIT Sloan Management Review, 58, 2, 10.

Tijan E., Aksentijević S., Ivanić K., Jardas M. (2019) Blockchain Technology Implementation in Logistics. Sustainability, 11, 4, 1185.

Tiwari S., Wee H. M., Daryanto Y. (2018) Big Data Analytics in Supply Chain Management between 2010 and 2016: Insights to Industries. Computers \& Industrial Engineering, 115, pp. 319-330.

Van der Vaart T., van Donk D.P. (2008) A Critical Review Of Survey-Based Research in Supply Chain Integration. International Journal of Production Economics, 111, 1, pp. 42-55.

Van Royen K., Poels K., Daelemans W., Vandebosch H. (2015) Automatic Monitoring of Cyberbullying on Social Networking Sites: From Technological Feasibility to Desirability. Telematics and Informatics, 32, 1, pp. 89-97.

Venkatesh V.G., Kang K., Wang B., Zhong R.Y., Zhang A. (2020) System Architecture for Blockchain Based Transparency of Supply Chain Social Sustainability. Robotics and Computer-Integrated Manufacturing, 63, 101896.

Vieira A.A., Dias L.M., Santos M.Y., Pereira G.A., Oliveira J.A. (2020) Supply Chain Data Integration: A Literature Review. Journal of Industrial Information Integration, 100161.

Wamba S.F., Dubey R., Gunasekaran A., Akter S. (2020) The Performance Effects of Big Data Analytics and Supply Chain Ambidexterity: The Moderating Effect of Environmental Dynamism. International Journal of Production Economics, 222, 107498.

Wang J.W., Wang H.F., Zhang W.J., Ip W.H., Furuta K. (2013) On a Unified Definition of the Service System: What Is its Identity? IEEE Systems Journal, 8, 3, pp. 821-826.

Weick K.E., Sutcliffe K.M., Obstfeld D. (1999) Organizing for High Reliability: Processes of Collective Mindfulness, Research in Organizational Behavior, 21, pp. 81-123.

Wong L.W., Leong L.Y., Hew J.J., Tan G.W.H., Ooi K.B. (2020) Time to Seize the Digital Evolution: Adoption of Blockchain in Operations and Supply Chain Management among Malaysian SMEs. International Journal of Information Management, 52, 101997.

WTO (2018) Available at: https://www.wto.org/english/tratop_e/agric_e/symposium_ag_policy_ landscape_e/s4_hussain.pdf

Xue X., Li X., Shen Q., Wang Y. (2005) An Agent-Based Framework for Supply Chain Coordination in Construction. Automation in Construction, 14, 3, pp. 413-430.

Yeniyurt S., Wu F., Kim D., Cavusgil S.T. (2019) Information Technology Resources, Innovativeness, and Supply Chain Capabilities as Drivers of Business Performance: A Retrospective and Future Research Directions. Industrial Marketing Management, 79, pp. 46-52.

Yu W., Jacobs M.A., Chavez R., Feng M. (2017) The Impacts of IT Capability and Marketing Capability on Supply Chain Integration: A Resource-Based Perspective. International Journal of Production Research, 55, 14, pp. 4196-4211.

Yu Y., Huo B. (2018) Supply Chain Quality Integration: Relational Antecedents and Operational Consequences. Supply Chain Management: An International Journal, 23, 3.

Zeng H., Chen X., Xiao X., Zhou Z. (2017) Institutional Pressures, Sustainable Supply Chain Management, and Circular Economy Capability: Empirical Evidence from Chinese Eco-industrial Park Firms. Journal of Cleaner Production, 155, pp. 54-65. 